\title{
MARXISMO, MÍSTICA E O MST: QUAL É O SEGREDO DO MST NA LUTA PELA REFORMA AGRÁRIA NO BRASIL?
}

\section{Graham Gerald McGeoch ${ }^{1}$}

Resumo: Este texto propõe apresentar a mística do Movimento dos Trabalhadores Rurais Sem Terra (MST) no Brasil e discutir à luz da teologia da libertaçáo e em diálogo com as ciências sociais, passos metodológicos para melhor compreender a importância ao MST na sua luta, resistência e projeto político. No primeiro momento do texto, são considerados estudos elaborados por cientistas sociais sobre o uso da mística no MST. Após, a discussão é analisada à luz da metodologia da Teologia da Libertaçấo. Finalmente, propóe um diálogo entre Ciências Sociais e Teologia da Libertação para melhor compreender a mística do MST e para apontar um caminho pelo qual outros movimentos sociais e militantes políticos possam incorporar a mística em suas lutas por justiça sem, simplesmente, se tornarem uma cópia do MST.

Palavras-chave: MST; Mística; Teologia da Libertação; Movimentos Sociais.

Abstract: This article presents the mistica of the Landless Workers' Movement (MST) in Brazil and, in light of the theology of liberation and in dialogue with social sciences, discusses methodological steps to better understand its importance to the MSTs struggle, resistance and political project. Firstly, the article considers some studies undertaken by social scientists into the mistica of the MST. Afterwards, the discussion is analyzed in light of the methodology of the theology of liberation. Lastly, the article proposes a dialogue between social sciences and the theology of theology in order to better understand the mistica of the MST and to indicate a way in which other social movements and political activists could incorporate mistica into their struggles for justice without simply copying the MST.

1 Teólogo e pastor da Igreja da Escócia (Church of Scotland). Professor da Faculdade Unida de Vitória, Brasil, e membro da Sociedade (Britânica) para Estudos sobre América Latina (Society of Latin American Studies). Contato: graham@faculdadeunida.com.br 
Keywords: Landless Workers' Movement (MST); Mistica; Liberation Theology; Social Movements.

\section{O QUE É O MST?}

O MST do Brasil é um dos maiores movimentos sociais do mundo. Algumas pesquisadoras estimam que ele tenha um milhão de membros e 100 mil crianças nas suas redes de escolas (Branford e Rocha, 2002, p. XII). Deve-se lembrar de que essas redes são reconhecidas pelo poder público e, neste artigo, quando se refere às escolas do MST, também estáo incluídas as Cirandas Infantis para crianças (Sem Terrinha) de 0-6 anos (Rossetto, 2016, p. 18). Outros pesquisadores sugerem que de $800 \mathrm{mil} \mathrm{a}$ um milhão de famílias são membros do MST (Vergara-Camus, 2014, p. 3). O próprio MST considera que já assentou 350 mil famílias desde sua fundação em 1984 (MST, 2018). Diferente de outros movimentos sociais, a proposta do MST é que pessoas e famílias assentadas permaneçam dentro do movimento ao lado das famílias que ainda lutam para o acesso à terra porque ele entende que esse acesso é apenas "um primeiro passo" (MST, 2018) para a realização da reforma agrária num processo de consciência revolucionária.

No livro Brava gente: a trajetória do MST e a luta pela terra no Brasil (2012), João Pedro Stédile (talvez o líder mais reconhecido do MST) descreveu as origens do movimento como uma resposta campesina à transformação socioeconômica provocada pela mecanização da agricultura na década 1970 . Este processo de mecanização da agricultura (e a introdução da soja) foi instigada pela ditadura militar, que ascendeu ao poder em 1964 através de um coup d'état, e implementada através do seu programa de "desenvolvimento e segurança nacional” (Tyson; Dreifuss; Black, 1998, p. 592). De acordo com Stédile, os camponeses foram expulsos das suas terras para a ditadura militar poder abrir caminho à introdução da mecanizaçáo da agricultura e, dentro de suas políticas públicas, que acompanhavam a mecanização da agricultura, 
nem todos os camponeses tiveram a opçáo de mudar para as grandes cidades ou serem transferidos para a regiáo Amazônica. Entâo, Stédile afirma que a alternativa restante para estes camponeses expulsos das suas terras foi se organizarem num movimento social e resistir ao programa de "desenvolvimento e segurança nacional" da ditadura militar (Stédile; Fernandes, 2012, p. 19).

Stédile também lembra que o MST é um herdeiro indireto das Ligas Camponesas que foram perseguidas e eliminadas pela mesma ditadura militar (Stédile; Fernandes, 2012, p. 20). A perseguiçáo mais intensa das Ligas Camponesas ocorreu entre 1964 e 1973 e deve-se lembrar que as perseguiçôes tinham como alvo diversos setores da sociedade brasileira tais como sindicatos, escolas, universidades, segmentos das forças armadas, organizaçóes de mulheres, movimentos sociais, igrejas e a imprensa (Skidmore, 1988). Porém, Stédile enfatiza essa herança indireta das Ligas Camponesas porque estavam localizadas no nordeste do Brasil enquanto o MST surgia (em seu primeiro momento) no sul do Brasil. A luta pela reforma agrária cria a conexão, além da oposição à ditadura militar, mas as Ligas Camponesas já tinham sido eliminadas pelo regime antes do surgimento oficial do MST em 1984. Além disso, Stédile também distancia o MST de outros movimentos sociais agrícolas da época. Ele nota que o Partido Comunista do Brasil (PCB), o Partido Trabalhista Brasileiro (PTB) e o Movimento dos Agricultores Sem Terra (Master) e, mais tarde, a União dos Lavradores e Trabalhadores Agrícolas do Brasil (Ultab) foram todos envolvidos na liderança e formação ideológica de movimentos sociais agrícolas no Brasil. Porém, o MST é diferente por não ter esta ligação direta com partidos políticos. Stédile lembra que está ligado ao trabalho pastoral da Igreja Católica Romana e da Igreja Luterana (Stédile; Fernandes, 2012, p. 21). Especificamente, ele está ligado às pastorais populares dessas igrejas que são influenciadas pela teologia da libertação. Em outras palavras, nesta linha, Stédile interpreta a origem do MST como consequência do trabalho da Comissão Pastoral da Terra (CPT) da Igreja Católica Romana que começou seu trabalho em 1975. A própria CPT reconhece que enquanto ela nasceu de uma iniciativa de bispos da Igreja Católica Romana da Amazônia, adquiriu um caráter 
ecumênico através do envolvimento de pessoas e lideranças de outras igrejas, notavelmente a Igreja Luterana. Por sua vez, Stédile interpreta a CPT como uma aplicação direta da teologia da libertação à prática pastoral popular das igrejas (Stédile; Fernandes, 2012, p. 22).

As reflexões de João Pedro Stédile expóem um contexto histórico importante para o surgimento do MST. Ele sinaliza a influência da ditadura militar, com sua política de "segurança e desenvolvimento nacional" e a perseguição e eliminação das Ligas Camponesas (um exemplo prévio para o MST da luta pela reforma agrária). Ele trata de fatores políticos, inclusive a relação de movimentos agrícolas com partidos políticos, e a relação do MST com o movimento sindical mais amplo. Mas, para Stédile, o diferencial do MST na luta pela reforma agrária, na sua contribuição maior dentro da Via Campesina e entre movimentos sociais é no reconhecimento da importância das pastorais populares de igrejas e da teologia da libertaçáo para seu surgimento.

$\mathrm{Na}$ sua história do MST, as jornalistas britânicas Sue Branford e Jan Rocha também notam essa importância apontando para a influência do trabalho da CPT e das comunidades eclesiais de base (CEBs) ao lado do movimento sindical liderado pela Central Única dos Trabalhadores (CUT), na formação do MST (2002, p. 27). Em seu estudo comparativo entre o MST e os Zapatistas, que será apresentado mais abaixo, Leandro VergaraCamus confirma a perspectiva elaborada por Stédile e nota que tanto o MST quanto os Zapatistas destacam sua autonomia em relaçáo ao Estado e partidos políticos. Porém, Vergara-Camus reconhece que enquanto os Zapatistas seguem uma política autônoma do Estado mexicano e não se aliam com partidos políticos, nem em tempos eleitorais, o MST é diferente. Ele participa nas eleiçóes democráticas e faz alianças estratégicas para instalar candidatos que simpatizam - mas não necessariamente membros do MST - com sua luta. Tem, também, uma relação especial com o Partido dos Trabalhadores (PT), especialmente durante o período de eleiçóes, mas não está ligado formalmente a ele. Talvez, isso ajude a entender a insistência do Stédile quando afirma que o MST difere de outros movimentos sociais por não estar ligado formalmente (por exemplo) ao PCB, PTB ou sindicatos. 
No entanto, no seu estudo sobre o MST, o antropólogo Jaume Vallverdu mostra que os fatores políticos que ajudaram a formar o MST incluem contextos de alianças amplas na luta pelos direitos humanos e contra a ditadura militar. O livro de Vallverdu, Los Sin Tierra: Mistica y resistencia en el MST de Brasil, o qual será discutido mais abaixo, na mesma linha que VergaraCamus, de que o MST participa em alianças amplas para promover sua luta pela reforma agrária, é influenciado profundamente pela história recente do Brasil na luta contra a ditadura militar, em prol dos direitos humanos e da redemocratização. Assim, o MST é comprometido com o projeto democrático da esquerda brasileira - às vezes chamada de frente popular - e especialmente com os sindicatos rurais e urbanos, e as cooperativas (2012, p. 42).

Para responder a pergunta sobre o que é o MST, fez-se uma breve síntese de aspectos políticos, históricos e religiosos que marcaram o movimento. Ele é considerado, pelos pesquisadores, um dos maiores movimentos sociais do mundo. Inspirou-se na organização dos camponeses expulsos das suas terras pelo programa de "desenvolvimento e segurança nacional" da ditadura militar. É um movimento social autônomo tanto do Estado quanto dos partidos políticos, todavia reconhecendo que ele negocia esta autonomia do Estado (por exemplo, o reconhecimento pelo poder público das suas Cirandas Infantis e escolas para Sem Terrinha) e dos partidos políticos (por exemplo, a participaçáo em alianças eleitorais náo estando formalmente filiado a um partido). Também, o MST advoga para uma vida alternativa ao modelo capitalista atual, compreendido como neoliberalismo. Ou seja, ele busca mais que um programa político de apenas redistribuição de terra do sistema latifundiário (Issa, 2014, p. 85). O MST pode ser compreendido como parte do movimento global contra o neoliberalismo. E é influenciado pela experiência anterior das Ligas Camponesas e a ação pastoral da teologia da libertação. Mas ele resiste a uma definição ligada apenas a essas duas heranças. 


\section{PERSPECTIVAS DAS CIÊNCIAS SOCIAIS E DA TEOLOGIA DA LIBERTAÇÃO SOBRE MÍSTICA E O MST}

João Pedro Stédile descreve mística como algo que diferencia o MST de outros movimentos sociais (Stédile; Fernandes, 2012, p. 131). O MST incorporou mística, desde seu surgimento, como uma prática social para sustentar o compromisso do povo na luta pela reforma agrária e para servir como um princípio organizativo do movimento. Ela faz parte das marchas, escolas, acampamentos, assentamentos, e outras iniciativas do MST. Em termos políticos, ao discursar sobre mística, Stédile nota que tradicionalmente a esquerda tem vergonha de seu uso, enquanto a direita não a considera importante. A esquerda política, de inspiração Marxista, facilmente associa mística com religião e depois deve lidar com o desprezo de Marx pela religiáo na frase célebre, tirado do ensaio dele sobre a filosofia de Hegel: "Religião é o suspiro da criatura oprimida, o ânimo de um mundo sem coração, e a alma de condiçóes sem alma. Ela é o ópio do povo" (Tucker, 1978, p. 54). Atualmente, a rejeição da religião pela esquerda marxista está sendo revisitada e revisada por teóricos diversos como Terry Eagleton (2009), Slavoj Zizek (2009) e Boaventura de Sousa Santos (2015), entre outros. A direita política não vê importância na mística por razóes parecidas. Ela reduz mística à religião, psicologia ou comportamento individual, portanto subjetivo e privado. Estas esferas não tem tanto peso para políticas de direita que se interessam mais em questôes relacionadas à esfera pública e suas instituiçóes (inclusive a institucionalidade).

João Pedro Stédile não é o único líder do MST que fala sobre mística. Ademar Bogo, outro líder do MST, tem descrito mística como uma leitura concreta da realidade para estabelecer uma base para um projeto de transformação (Bogo, 2001, p. 71). É interessante que, de acordo com Bogo, mística permite o MST viver um futuro antecipado. Ou seja, a partir de uma leitura concreta da realidade, mística permite uma abertura para o mundo porvir seja ele terras redistribuídas, ou um projeto político mais abrangente. Essa reflexão foi publicada em um pequeno panfleto com contribuiçóes 
também de Leonardo Boff e Frei Betto. Bogo é um líder do MST enquanto Boff e Betto são assessores do movimento. Boff está entre os mais conhecidos teólogos da libertação. Betto é frade dominicano e jornalista e foi um assessor especial do então Presidente da República, Lula, em seu primeiro mandato e, também, foi coordenador da Mobilização Social do programa Fome Zero (Betto, 2006). O panfleto no qual participaram os três, Valores de uma prática militante (2001), é amplamente difundido no MST e em outros movimentos sociais, assim como em igrejas no Brasil.

Todavia, apesar de existir várias publicaçôes teológicas (dentro da teologia da libertação) sobre mística, (e Valores de uma prática militante poderia ser considerada uma delas) ainda não há estudos que façam uma reflexão teológica específica ou sistemática sobre a mística do MST. Os próprios Boff e Betto publicaram um livro juntos sobre mística em lutas políticas, Mistica e espiritualidade (1999), fruto de um curso que eles promoveram em São Paulo para líderes nacionais de movimentos sociais e lutas políticas. Retomarei esse diálogo abaixo. Pedro Casaldáliga e Jose Maria Vigil - bispo e teólogo, respectivamente - publicaram um livro, Espiritualidade da libertação (1994), como uma reflexão geral que considera mística como uma forma de espiritualidade militante (1994, p. 75). E, mais recentemente, Marcelo Barros, um monge beneditino e assessor de diversos movimentos sociais no Brasil, escreveu um livro sobre espiritualidade socialista latino-americana no século XXI. Nele, Barros revisita a obra e filosofia de José Martí e descreve a mística como "[...] uma motivação vivencial, mais do que intelectual e que dá sentido profundo à luta e ao trabalho cotidiano" (2011, p. 76). A obra e filosofia de José Martí são de suma importância para movimentos sociais e políticos latino-americanos que se inspiram no marxismo, inclusive o MST. Barros nota que enquanto muitas revoluçóes sociais e políticas se mostram hostis à religião, nos movimentos revolucionários latino-americanos, a fé cristã, a religião indígena e as religiôes afro-brasileiras (ou afro-latino-americanas, se considerarmos a região inteira) são ativamente incorporadas nos processos revolucionários (2011, p. 76). Também, pode-se notar, de passagem, o trabalho de outros teólogos da libertação que refletiram sobre 
mística e política de forma mais geral. Os livros de Gustavo Gutiérrez, Beber en su proprio pozo (1983), e de Jon Sobrino, Spirituality of liberation (1990) oferecem reflexôes de teólogos da libertação sobre mística. O argumento não é que há uma falta de reflexão da teologia da libertação sobre mística e espiritualidade mas que apesar disto ainda não há uma reflexão elaborada, seguindo a própria metodologia da teologia da libertação, sobre mística do MST. Ou seja, as suas reflexôes são generalizadas e não necessariamente acompanham a prática do MST e outros movimentos sociais. Ao contrário, são pesquisadores e pesquisadoras das Ciências Sociais que têm acompanhado e refletido mais detalhadamente sobre mística do MST.

Daniela Issa, uma socióloga da École des hautes études en sciences sociales (Escola Superior de Estudos em Ciências Sociais) em Paris, descreve a mística como "enraizada na ética religiosa da teologia da libertação - na opção preferencial pelos pobres - que é melhor explicada pelo conceito de Weber de 'afinidade eletiva'” (Issa, 2014, p. 86). No seu artigo, ela interpreta a teologia da libertaçáo como algo que surge do Vaticano II e subsequentemente do encontro episcopal de Medellín da Igreja Católica Romana na América Latina. É importante ressaltar que alguns teólogos da libertação contestariam essa leitura sobre o surgimento de sua teologia, preferindo localizá-lo no contexto político latino-americano na década de 1950 em particular, mas não exclusivamente na experiência cubana.

Também, como cientista social, ela prefere situar "a opção preferencial pelos pobres" no terreno da sociologia e não da teologia. Em termos sociológicos, ela consta que esta opção da teologia da libertação pode ser explicada pelo conceito de "afinidade eletiva” em Max Weber. O sociólogo Michel Lowy escreveu sobre "afinidade eletiva” em Weber no seu artigo, Sobre o conceito de "afinidade eletiva" em Max Weber (2011), originalmente publicado na França em 2005. Lowy articula esse conceito em relação ao campo da religião, economia, cultura, ação comunitária e política, notando que ela se expressa "entre o estilo de vida exigido pela religião e o estilo de vida socialmente condicionado pelos grupos de status e pelas classes" (2011, p. 136). No seu artigo ele está tentando superar a antiga divisáo na sociologia 
entre Weber e Marx e apresenta uma leitura de classes sociais e estilos de vida religiosa numa relação recíproca. E é por meio desta perspectiva que Issa fala da teologia da "opção preferencial pelos pobres" como sociologia por meio da "afinidade eletiva".

Além disso, Issa nota que mística no MST muitas vezes é apresentada na literatura das Ciências Sociais brasileiras como "[...] a representação através de palavras, arte, simbolismo, e música das lutas e cotidiano deste movimento social” (2014, p. 87). É uma forma de produção cultural. No entanto, ela acompanha as reflexôes acadêmicas publicadas fora do Brasil sobre o MST. Nisto ela indica as diferenças (e problemas) na tradução da palavra "mística" do português para a língua inglesa. De acordo com Issa, traduçóes possíveis incluem: "'mysticism', 'elan', 'milleniarism', 'mystique', 'mystical component" (2014, p. 88). A tradução da palavra é problemática, como demonstra Issa, porque, quando referimos ao "poder da mística" ou "praticando mística" em português, a tradução para a língua inglesa nem sempre abrange os diferentes usos da palavra pelo MST - substantivo, verbo etc - e seu conceito.

Então, outra questão que aparece é que as traduções usadas na língua inglesa suprimem uma contribuição da teologia da libertação (o que tem eco nas observaçôes de líderes da primeira geração como Stédile, por exemplo) que questiona a necessidade da teologia de separar o espiritual e material. Ou seja, mística no MST é algo histórico que parte da realidade concreta e nem toda tradução para o inglês deixa isso claro, abrindo possibilidade de má interpretação, especialmente quando a maioria dos trabalhos é feita por pessoas não familiarizadas com teologia, muito menos com debates internos da teologia da libertação. As observações dela sobre tradução, também refletem alguns aspectos do trabalho feito por Enrique Dussel sobre a tradução para a língua inglesa de conceitos chaves da teologia da libertaçáo tais como pueblo. Frequentemente, é traduzida como people, apesar do fato de que esta palavra em inglês não carrega as mesmas conotações de classes sociais que são implícitas no castelhano (e português).

Jaume Vallverdu, um antropólogo ligado à Universidade Aberta de Catalonia, publicou um estudo extenso sobre a mística do MST. Ele identificava 
fontes importantes para o assunto dentro da formação ideológica comunista, da teologia da libertação e da liturgia de rituais rurais coletivos (2012, p. 133). Ele afirma que mística no MST recebeu críticas severas por algumas partes da esquerda política que, na sua crítica, empregavam a frase de Marx sobre religião como ópio do povo. Ele identifica três aspectos fundamentais provenientes da herança da vida camponesa: (1) a vida contemplativa campesina, (2) a música e poesia campesina, (3) a devoção campesina (2012, p. 137). Para Vallverdu, os três aspectos contribuem para produzir o mundo simbólico dos militantes do MST. Novamente, como Issa, ele prioriza mística como produção cultural. Ao mesmo tempo, Vallverdu indica que este mundo simbólico está enraizado na ação pastoral da teologia da libertação e na consciência crítica desenvolvida por Paulo Freire, e faz uso de um imaginário popular das lutas brasileiras (2012, p. 136).

Leandro Vergara-Camus, um cientista social da Escola de Estudos Orientais e Africanos em Londres, escreveu um livro que faz uma comparação entre o MST e os Zapatistas. Land and freedom: the MST, the Zapatistas and peasant alternatives to neoliberalism (2014) descreve mística no MST como "uma comunidade imaginada” que reforça a pertença através de práticas culturais e simbólicas. A pertença traz coesão e militância ao movimento (2014, p. 104). Nisto, Vergara-Camus utiliza o conceito "comunidade imaginada" de Benedict Anderson e seu livro clássico, Imagined Communities (1983). Mais adiante no seu estudo, Vergara-Camus situa mística dentro de uma prática narrativa que captura a saída do meio urbano em direção a um passado idealizado do campo (2014, p. 185). Esta narrativa exerceu muita força na América Latina durante as migraçôes do campo à cidade no século XX.

Daniela Issa, além de analisar a mística, apresenta uma descrição de mística do MST oferecida por um líder do movimento. Ela cita:

A celebração é linda quando é praticada com brevidade, certa solenidade e simplicidade. É bom usar gestos, símbolos, expressōes culturais, testemunhos pessoais, mas é preciso evitar que se torne uma representação meramente teatral. 
Uma mística não deve ser expressa para fins de entretenimento - sem surpresas ou sensacionalismo. As pessoas devem estar envolvidas no processo de preparação. Se um poema é usado, uma cópia do texto deve ser fornecida para que as pessoas tenham acesso ao que está sendo lido e o mesmo para a música.

É importante evitar o uso da mística para decorar uma reunião... Não deve se tornar a tarefa de 'especialistas', embora alguns sejam mais criativos e sensíveis do que outros. Náo deve ocupar todo o foco... Não deve se transformar em uma competiçấo... Algo que funcionou no Nordeste do Brasil seria fora do contexto e inautêntico no Sul. A preparação é necessária para evitar a improvisação...

As Místicas podem ser realizadas no início de uma reunião para ajudar a chamar a atenção de todos e recordar o espírito que une o grupo, mas uma canção, leitura de poesia, silêncio ou 'palavra de ordem' pode ser apresentada em qualquer momento apropriado (2014, p. 93).

Tal descrição tem ressonância com aquela oferecida por Stédile. Enquanto o líder citado por Issa captura a forma e os meios apontando para gestos, símbolos, expressões culturais, testemunhos pessoais, poesias e música (2014, p. 93), Stédile enfatiza mais os símbolos do MST e sua incorporação em mística. Ele diz que mística deve ter uma bandeira, hino, palavra de ordem, ferramentas para trabalho, e frutos do trabalho. Ele chama atenção para o uso de boné, placas e música do MST. E afirma que mística foi aprendida mais com a igreja do que com outros movimentos sociais (2012, p. 133).

Entre os cientistas sociais, há certo consenso que mística no MST tem suas raízes em rituais religiosos, formação ideológica, e o trabalho de Paulo Freire - através de códigos que apresentam temas geradores para o conteúdo de uma educação libertadora (1993). Também, ela é influenciada pelo teatro do oprimido de Augusto Boal - o teatro da rua implica que qualquer pessoa pode atuar, quer dizer, qualquer pessoa pode interpretar e iniciar ação que desmascara verdades sobre sociedades e culturas (Boal, 2003). Porém, há 
ênfases diferentes entre cientistas sociais sobre as influências por parte da formação política e ideológica da esquerda, da teologia da libertação e sua formação pastoral, e da conscientização de Paulo Freire e do teatro de rua de Augusto Boal na elaboração e desenvolvimento de mística do MST.

São cientistas sociais que têm dedicado maior labor sistemático no estudo sobre mística no MST. E, muitas vezes, os escritos não fazem reflexões teológicas, ou tentam evitar a teologia de mística no MST. A análise de Weber sobre 'afinidades eletivas' e teorias mais amplas das Ciências Sociais sobre produção cultural, simbolismo e pertença influenciam as interpretações de mística no MST. Porém, frequentemente a liderança do MST nota que é precisamente a teologia de mística, e a ligação com a teologia da libertação, que diferencia o MST dos outros movimentos sociais. E é exatamente esta ligação e afinidade teológica que trazem críticas feitas por partidos políticos da esquerda e de outros movimentos sociais. Embora alguns teólogos da libertação fossem assessores do MST - Leonardo Boff, Frei Betto, Marcelo Barros - e dedicarem esforço à mística, suas concepções de mística são importadas para o MST através das suas formaçóes católica romana. Na próxima parte, discutiremos mais e veremos o porquê de esta prática de importação não ser uma metodologia da teologia da libertação e não condizer à uma reflexão eficaz sobre a prática de mística no MST.

\section{PASSOS METODOLÓGICOS SOBRE MÍSTICA E A TEOLOGIA DA LIBERTAÇÃO}

Conforme já escrito acima, a teologia da libertação latino-americana tem reflexôes mais generalizadas sobre mística. Várias figuras influentes nesta teologia optaram por explorar mística em relação à assim chamada espiritualidade libertadora. Perguntaram Boff e Betto aos movimentos sociais e ativistas políticos - "Qual é a força secreta que sustenta todos estes grupos? Donde vem esperança para continuar a sonhar, a resistir e a querer uma sociedade mais humana...?” (Boff; Betto 1999, p. 10). Para responder esta pergunta, 
os autores oferecem quatro fontes e as explicam no primeiro capítulo de seu livro, Mistica e espiritualidade (1999). Nota-se que apenas uma das fontes é religiosa. Primeiro, há a utopia original do cristianismo de uma sociedade fraterna, justa e participativa, com a inclusão dos pobres, e uma percepção da divindade em cada ser humano. A segunda fonte é o ideal emancipatório da revolução francesa com uma visão de uma democracia participativa e popular. $\mathrm{Na}$ terceira, fala-se da visão do socialismo e marxismo, que se indagam diante da miséria e promulgam revolução como um ato de amor. E por fim, na quarta, há o humanismo radical com uma ética de compaixão e solidariedade. Boff enfatiza que este tipo de mística, "não significa despistar a resposta às questôes formuladas, nem mistificar a realidade, mas colher seu lado mais luminoso, aquela dimensão que alimenta as energias vitais para além do princípio do interesse, dos fracassos e sucessos" (1999, p. 11).

É baseado no contexto destas quatro fontes identificadas por Boff e Betto - utopia original do cristianismo, os ideais da revolução francesa, visão de amor revolucionário do socialismo e marxismo, e humanismo radical - que o MST e as comunidades eclesiais de base falam sobre mística. O importante, para teólogos da libertação (e para o MST mesmo), é que a palavra mística pode carregar significado religioso assim como pode ser destituída do significado religioso. Para Boff e Betto, mística está enraizada no reconhecimento do mistério da vida (1999, p. 11), mas sem mistificar a vida e a realidade. No seu livro Espiritualidade da libertação (1994), Casaldáliga e Vigil apontam para o mesmo caminho que Boff e Betto e dizem que mística é uma espiritualidade "mais profundamente humana" (1994, p. 27). Também, deve ficar claro que dessas quatro fontes esboçadas por Boff e Betto, eles estão em diálogo com o que tradicionalmente é conhecido como cristianismo de esquerda.

Todavia, o importante para a teologia da libertação (e talvez ligeiramente diferente da literatura das Ciências Sociais sobre o MST), mística é compreendida como algo já presente no MST independentemente da análise preferida com relação às quatro fontes de Boff e Betto. Ou seja, mística faz parte do MST e não se pode entendê-lo sem considerar este aspecto 
do movimento. A mística já presente define o MST, e enquanto pode ter fontes inspiradoras, ela não está importada ou acrescida ao movimento. Tal abordagem e entendimento deveria fazer a teologia da libertação voltar para uma das suas mais básicas metodologias. Teologia vem em segundo lugar (Gutiérrez e Segundo). Gutiérrez dá conteúdo para esta metodologia na sua obra clássica, A Theology of Liberation (2001), da seguinte maneira: "A teologia deve ser uma reflexão crítica sobre a humanidade, sobre princípios humanos básicos" (2001, p. 55). Para refletir criticamente sobre humanidade, a teologia precisa das Ciências Sociais para aproximar-se da realidade. E, Juan Luis Segundo, trabalhando na mesma direção, afirma que "[...] toda questão teológica começa com uma situação humana. Teologia é o segundo momento... compromisso vem primeiro" (1982, p. 79). O uso das Ciências Sociais é para ajudar a aprofundar o compromisso com uma situação humana. Somente depois do compromisso, da aproximação da realidade, é que é possível fazer teologia. No caso especifico de mística no MST, é uma questão metodológica que a teologia (até a teologia da libertação) não faça uma intervenção sem primeiro levar em consideração as reflexôes das Ciências Sociais sobre mística.

Voltando para as observaçóes de Boff e Betto sobre as quatro fontes de mística, outro aspecto a notar é que o caminho que elas abrem para reflexóes teológicas sobre mística não é necessariamente eclessiocêntrica. Em outras palavras, mística não se restringe ou se baseia necessariamente na igreja ou numa eclesiologia. Tampouco é possível interpretar mística no MST exclusivamente como uma mística cristã, se seguirmos a metodologia originária da teologia da libertação e aproximarmos ao MST pelas Ciências Sociais antes de fazer a reflexão teológica. A primeira geração de líderes do MST enfatiza muito a ligação com a pastoral popular da Igreja Católica Romana e da Igreja Luterana, e muitos assessores do MST vindos da teologia da libertação estão ligados à Igreja Católica Romana. Mas, na situação humana do MST consta a presença de outras religióes nos acampamentos e assentamentos, para náo falar de igrejas oriundas do movimento pentecostal. Marcelo Barros, outro teólogo da libertação e assessor do MST, no seu estudo sobre lutas pela 
libertação na América Latina no século XXI, afirma que "[...] a mística é universal” (2011, p. 36): é a esperança que motiva um movimento popular ou uma comunidade eclesial de base (2011, p. 33). Este universalismo de Barros precisa estender-se para incluir experiências pentecostais (e neopentecostais) e outras religióes presentes dentro do MST. E, a partir das quatro fontes de Boff e Betto, deve-se estender para ateus.

A primeira possível fonte descrita por Boff e Betto é a utopia original do cristianismo de uma sociedade fraterna, justa e participativa, incluindo os pobres, e ciente da divindade em cada ser humano. Alguns poderiam interpretar isto como uma forma de excluir outras tradições religiosas das fontes da mística do MST. Porém, as outras três fontes descritas por Boff e Betto são inspiradas diretamente em movimentos políticos e filosóficos, e não religiosas.

Também, um conhecimento superficial do cristianismo na América Latina e o cristianismo da teologia da libertação, com sua opçáo preferencial pelos pobres, faz lembrar que o cristianismo dos pobres, na verdade da Igreja latino-americana, é plurirreligioso. Ele tem muitas espiritualidades, humanismos e sincretismos diferentes (Irarrázaval, 2003, p. 506). Para Frei Betto, "[...] a dificuldade da teologia da libertação é captar a riqueza da espiritualidade dos pobres" (1999, p. 44). Segundo Betto, esta dificuldade se localiza no fato de que a teologia da Igreja não necessariamente coincide com a mística vivida pelos pobres. (Simultaneamente, pode-se dizer que mística oferece uma crítica para algumas propostas da teologia da libertação que não fazem teologia como ato segundo e, portanto, não conseguem acolher a mística vivida pelos pobres e mapeada pelas Ciências Sociais). É por isso que recuperar a metodologia original da teologia da libertação desenvolvida por Gutiérrez e Segundo se torna importante no estudo de mística no MST.

A tendência na teologia da libertação é interpretar a mística dos pobres como devoção popular na América Latina, e afirmar que ela assimila tradiçôes religiosas diferentes dentro do cristianismo numa espécie de sincretismo (Boff, 1981). Por exemplo, a teologia da libertação, em diálogo com tradições indígenas, religióes afro-latino-americanas, e movimentos sociais abraça místicas oriundas de Pacha Mama do Perú (a terra-máe, que na forma de montanhas 
aceita a penitência do povo) (Boff; Betto, 1999, p. 44); de versóes indígenas da Tierra sin Males (“Terra sem mal”, que é uma visão do mundo porvir) (Agenda Latino-americana 2013); dos rituais da espiritualidade africana (por exemplo, Candomblé) nos quais deuses africanos e santos cristãos têm suas encarnaçôes complementares. Além disso, a teologia da libertação tem desenvolvido teorias sobre religião e economia capitalista que visam a sacramentalização do Mercado (ou neoliberalismo) em expressóes religiosas, particular, mas não exclusivamente dos movimentos neopentecostais do cristianismo latino-americano. Falar de uma mística cristã no contexto da teologia da libertação quer dizer necessariamente falar de um macro ecumenismo ou plurireligiosidade que abraça outras tradiçôes religiosas e bases filosóficas.

\section{PROPOSTAS PARA UMA TEOLOGIA DA LIBERTAÇÃO DE MÍSTICA NO MST}

Se a teologia da libertação quer refletir sobre mística no MST, oferecendo mais que uma reflexão geral sobre a mística e depois aplicando esta reflexão geral ao MST (ou qualquer outro movimento social ou organizaçáo política), ela precisa ir de encontro com as experiências vividas nos acampamentos, assentamentos, escolas e liderança do MST. Ela precisa se aproximar à realidade do MST, mediada pelas Ciências Sociais. Ao mesmo tempo, partindo da realidade mediada, essas experiências vividas podem refletir a "comunidade imaginada" (Vergara-Camus, 2014, p. 104) do MST. E, por sua vez, esta "comunidade imaginada" pode ser influenciada pela "formação ideológica comunista, a teologia da libertação e a liturgia de rituais coletivos rurais" (Vallverdu, 2012, p. 133).

Daniela Issa articula que a influência da teologia da libertação no MST significa que, enquanto a mística carrega uma semelhança etimológica às concepçóes religiosas de mistério (mystery) ou misticismo (mystical), ela na verdade age contra as perspectivas tradicionais Judaico-Cristãs do Reino 
de Deus como recompensa na vida depois da morte para o sofrimento experimentado neste mundo (2014, p. 89). Além disso, ela entende que mística no MST é uma experiência comunitária (2014, p. 89). Ela não se situa na subjetividade ou particularidade. Jaume Vallverdu, também interpreta mística no MST de forma parecida. Ele reforça a perspectiva de experiência comunitária dizendo que mística no MST faz visível e viável a luta, a resistência e a transformação (2012, p. 136).

As abordagens de Issa e Vallverdu se aproximam da questão marxista filosófica de materialismo histórica em que a Mística no MST é produzida e condicionada pelas condiçóes materiais (e não subjetivas) da "comunidade imaginada” e suas lutas, resistências e conquistas. É importante esclarecer mais essa interpretação nas condições materiais do movimento, que é oferecida pelas Ciências Sociais e, portanto, fará parte da proposta de diálogo com a "teologia que vem em segundo momento" (Gutierrez, 2001; Segundo, 1976), ou seja, a teologia da libertação.

O diálogo entre as Ciências Sociais e a Teologia, entre o materialismo histórico e a teologia, entre cristãos e marxistas não é novo. Ele remete à década 1970. Deve-se lembrar de que é nessa época que os grupos formadores do MST vão surgir contra a ditadura militar. E que é também nessa época o surgimento de uma reflexão crítica sobre a humanidade e o compromisso cristão. Por isso, é importante voltar à década de 1970 e traçar um pouco o diálogo Cristão-Marxista, particularmente os elementos que vão influenciar a pastoral popular e a teologia da libertação. Afinal, tanto para cientistas sociais quanto para líderes do MST, ambas são decisivas na formação e o surgimento do MST e, portanto, influenciam sua mística.

No seu estudo histórico, A Marxist looks at Jesus (1976), Milan Machovec considera que intelectuais Marxistas tinham a tendência de interpretar "todas as ideias históricas pelos interesses e desenvolvimentos socioeconômicos, ou seja, explicam ideologia através da sua base econômica" (1976, p. 21). (É o materialismo histórico). Ele, também, explica que o ateísmo de Marx deveria ser interpretado mais como uma crítica à religião da sua época do que como uma afirmação positiva e opção de vida. Machovec reconhecia que “[...] 
ateísmo tem sentido apenas como crítica, limitado no espaço e tempo, aos modelos dominantes usados pela fé religiosa” (1976, p. 21). Nesta afirmação, seguindo uma corrente dentro do próprio cristianismo que remonta ao martírio de Policarpo no século II, mostra-se ciente da publicação do filósofo marxista, Ernst Bloch, Ateísmo no Cristianismo (originalmente publicado em 1968). Talvez a afirmação de maior interesse para mística no MST do Machovec é a qual ele diz que se a metodologia marxista é aplicada adequadamente à realidade, ela fornece novas realidades vivenciais que não são utopias (1976, p. 26). Esta metodologia marxista tem ressonância nas palavras já citadas de Ademar Bogo, líder do MST, quando ele diz que mística permite ao MST viver um futuro antecipada (2001, p. 71). Enquanto Machovec propóe a necessidade de uma releitura de escatologias marxistas, o MST, através de mística, já está fazendo na prática esta releitura.

O caminho e escolha tomados pelo MST têm uma escatologia baseada no desvelamento de novas realidades vividas - através de mística. Depois estas novas realidades vividas são usadas para sustentar o compromisso de pessoas com o MST e sua luta, especialmente depois de serem expulsas de um acampamento pelo Estado ou por forças paramilitares, ou mais positivamente, depois de serem assentadas em terras novas.

O estudo do Machovec foi importante para a teologia da libertação. O livro foi traduzido como Jesus para Ateus tanto em português quanto em castelhano. Não quero tratar as nuanças do título aqui. Porém, quero referirme ao trabalho teológico de Juan Luis Segundo, teólogo da libertação, que respondeu ao livro do Machovec e seguiu a metodologia proposta por ele.

Inspirado pela metodologia de Machovec, Segundo embarcou numa investigação teológica sobre Jesus de Nazaré para ateus. Nas suas próprias palavras, ele quis remover religião e teologia do monopólio do cristianismo sobre Jesus. No seu estudo, A História Perdida e Recuperada de Jesus de Nazaré (1991), Segundo propóe um diálogo sobre Jesus que se baseia na proposta do marxismo-ateísmo do Machovec e em seguida ele esboça o, hoje bem conhecido, conceito de "fé antropológica". A "fé antropológica" proposta pelo Segundo não é necessariamente uma fé religiosa ou fé teológica. $\mathrm{O}$ 
interesse de Segundo era esboçar um conceito de fé que apelasse "aos ateus". Ele utiliza a "fé antropológica" para explicitar o significado e valor que o ser humano dá ao conhecimento socializado. No caso específico de Segundo, ele aposta - uma das palavras favoritas dele - nesta "fé antropológica" para esclarecer os valores que permitem uma pessoa apostar que uma sociedade mais justa é, também, uma sociedade mais feliz (1997, p. 53). Para Segundo, esta "fé antropológica" navega tanto com subjetividade quanto com objetividade na percepção do mundo de alguém, por isso o conhecimento socializado (1991, p. 53). Porém, o significado ou o valor, para que um futuro possível, diferente do presente vivido, seja proporcionado, não pode se tornar absoluto. Se for assim, o significado ou o valor se torna o que Segundo chama de "informação transcendente" expondo valores como utópicos, interpretados como sendo além dos limites das experiências vividas, e, portanto, contra-produtivo na luta pela transformação social que precisa partir das experiências vividas (1997, p. 54).

Mística no MST, teológica e praticamente, se situa na proposta e aposta de Segundo sobre uma "fé antropológica". Mística incorpora a metodologia do Machovec e Segundo de remover o monopólio da religião e da teologia, o que se torna importante para acompanhar seu significado e valor para o MST, interpretado como um movimento social e não um movimento religioso. Isto ajuda explicar por que cientistas sociais notam que o marxismo, o socialismo, as espiritualidades afro-brasileiras, as experiências neopentecostais e a prática pastoral da teologia da libertação, contribuem à mística do MST. Nas palavras de João Pedro Stédile "A mística só tem sentido se faz parte da tua vida... Antes só imitávamos [a Igreja]... Quando forçávamos a cópia, não dava certo... A mística faz com que as pessoas se sintam bem” (2012, p. 132). A mística do MST não é ideológica, utópica ou alienadora. Ela reflete e responde às experiências vividas dos acampamentos e assentamentos, escolas e liderança do MST. Ela não segue um caminho transcendental, mas se baseia nas experiências da luta, resistência e redistribuição de terra entre seus membros. Ela ajuda a antecipar debates sobre materialismo histórico em correntes marxistas. E ela se situa na fé antropológica do teólogo da 
libertação, Juan Luis Segundo, dando significado e valor à "comunidade imaginada" por meio do conhecimento socializado.

\section{CONSIDERAÇÓES FINAIS}

O MST é o maior movimento social do mundo. João Pedro Stédile (o líder mais reconhecido do MST) tem descrito mística no MST como algo que diferencia o movimento de outros movimentos sociais. O MST incorpora mística como uma prática social para sustentar o compromisso do povo na luta pela reforma agrária, promovendo mística como um princípio organizativo do movimento.

De acordo com cientistas sociais, a mística do MST tem suas raízes em rituais rurais, formação ideológica, na pedagogia do oprimido de Paulo Freire e no teatro do oprimido de Augusto Boal. Mística tem uma bandeira, hino, placas, palavras de ordem, música, ação e reflexão.

Cientistas sociais têm estudado a mística do MST mais sistematicamente que os teólogos (inclusive teólogos da libertação). Todavia, embora a análise das Ciências Sociais seja compreensiva, ela não engaja com a mística teologicamente. E isto descarta a perspectiva do próprio MST porque ele articula mística teológica e praticamente, insistindo que é exatamente esta articulação mesma que diferencia o MST de outros movimentos sociais.

A teologia da libertação não possui uma reflexão sistemática sobre mística no MST, mas oferece reflexôes mais gerais sobre a mística. Por sua vez, não se pode negar que estas reflexóes gerais exercem certa influência nos debates internos do MST. Diálogos Cristáo-Marxistas, da década de 1970, e, especificamente, o trabalho do teólogo da libertaçáo, Juan Luis Segundo, oferecem perspectivas mais perspicazes. $\mathrm{O}$ uso de mística na luta do MST e seu apontamento como significado e valor de conhecimento humano socializado indicam caminhos náo religiosos ou teológicos com quais outros movimentos sociais podem expressar mística nas suas lutas sem simplesmente copiar (forçadamente) o MST. 


\section{REFERÊNCIAS}

ANDERSON, Benedict. Imagined Communities. Londres: Verso, 1983.

BARROS, Marcelo. Para onde vai nuestra América: espiritualidade socialista para o século XI. São Bernardo do Campo: Nhanduti Editora, 2011.

BETTO, Frei. Mosca azul. São Paulo: Rocco, 2006.

BOAL, Augusto. Games for actors and non-actors. Londres: Routledge, 2003.

BOFF, Leonardo. Igreja, Carisma e Poder. Petrópolis: Vozes, 1981.

BOFF, Leonardo; BETTO, Frei. Mistica e espiritualidade. Rio de Janeiro: Rocco, 1999.

BOFF, Leonardo; BETTO, Frei; BOGO, A. Valores de uma prática militante. São Paulo: Consulta Popular, 2001.

BRANFORD, Sue; ROCHA, Jan. Cutting the wire: the story of the landless movement in Brazil. Londres: Latin America Bureau, 2002.

BLOCH, Ernst. Atheism in Christianity. Londres: Verso, 2009.

CASALDÁLIGA, Pedro; VIGIL, José María. Espiritualidade da libertação. Petrópolis: Vozes, 1994.

EAGLETON, Terry. O debate sobre Deus: razão, fé e revelação. Rio de Janeiro: Nova Fronteira Participaçóes, 2009.

FREIRE, Paulo. Pedagogy of the oppressed. Londres: Penguin, 1993.

GUTIERREZ, Gustavo. Beber en su proprio pozo. Lima: CEP, 1983.

IRARRAZAVAL, Diego. Polémica sobre la cultura religiosa del pobre In: COMBLIN, José. A esperança dos pobres vive. São Paulo: Paulus, 2003. p. 501-514.

ISSA, Daniela. Praxis of Empowerment: Mística and mobilization in Brazil's Landless Rural Workers' Movement (MST). In: STAHLER-SHOLK, Richard 
et al. Rethinking Latin American social movements: radical action from below. Londres: Rowman and Littlefield, 2014. p. 85-100.

LOWY, Michel. Sobre o conceito de "afinidade eletiva" em Max Weber. Plural: Revista de Ciências Sociais da USP, São Paulo, v. 17, n. 2, p. 129-142, 2011. MACHOVEC, Milan. A Marxist looks at Jesus. Philadelphia: Fortress Press, 1976.

MST. Quem somos? 2018. Disponível em: <http://www.mst.org.br/quemsomos>. Acesso em: 30 jan. 2018.

ROSSETTO, Edna Rodrigues Araújo. A organização do trabalho pedagógico nas cirandas infantis do MST: lutar e brincar faz parte da escola de vida dos Sem Terrinha. 2016. Tese (Doutorado em Educação)-Faculdade de Educação da Universidade Estadual de Campinas, Unicamp, Campinas, 2016.

SEGUNDO, Juan Luis. The liberation of theology. Maryknoll: Orbis Books, 1976.

. A história perdida e recuperada de Jesus de Nazaré. São Paulo: Paulus, 1997.

SKIDMORE, Thomas. The politics of military rule in Brazil 1964-1985. New York: Oxford University Press, 1988.

SOBRINO, Jon. Spirituality of liberation: towards political holiness. Maryknoll: Orbis Books, 1990.

SOUZA SANTOS, Boaventura. If God were a human rights activist. Stanford: Stanford University Press, 2015.

STÉDILE, Joao Pedro; FERNANDES, Bernardo Mançano. Brava gente: a trajetória do MST e a luta pela terra no Brasil. São Paulo: Expressão Popular, 2012.

TUCKER, Robert (Org.). The Marx-Engels Reader. New York: Norton, 1978. 
TYSON, Brady et al. Brazil: Militocracy and frustrated democratization. In: BLACK, Jan Knippers (Org.). Latin America: its problems and its promise. Oxford: Westview Press, 1998. p. 591-606.

VALLVERDU, Jaume. Los Sin Tierra: Mística y resistencia en el MST de Brasil. Tarragona: URV Publicaciones, 2012.

VERGARA-CAMUS, Leandro. Land and freedom: the MST, the Zapatistas and peasant alternatives to neoliberalism. Londres: Zed Books, 2014.

ZIZEK, Slavoj. The Fragile Absolute: Or, Why is the Christian Legacy Worth Fighting For? Londres: Verso, 2009.

Recebido em: 05/02/2018 Aprovado em: 07/06/2018 